\title{
Effect Of Water Content On Characteristics Fuel From The Municipal Solid Waste Through The Pyrolysis Process
}

\author{
Imron Rosyadi ${ }^{1}$, Ni Ketut Caturwati ${ }^{2}$ Ahmad Fauzi ${ }^{3}$ \\ Jurusan Teknik Mesin, Fakultas Teknik, Universitas Sultan Ageng Tirtayasa \\ Jl. Jenderal Sudirman KM 03 Cilegon 42435 \\ E-mail: imronjtm@untirta.ac.id
}

\begin{abstract}
The increase in the population of Indonesia is proportional to the increase in the amount of waste produced. Municipal solid waste (MSW) especially organic waste, can be used as solid fuel by means of the torefaction process. Torefaction is a thermo-chemical heat treatment method for biomass conversion that takes place at a temperature of $200 \mathrm{oC}$ to $300 \mathrm{oC}$ under conditions of atmospheric pressure and in the absence of oxygen. The purpose of this study was to determine the effect of moisture content on calorific, proximate and ultimate values of torefaction samples using municipal solid waste. Setting the water content in the mixed sample $(30 \%$ rice $+70 \%$ wood) with variations in moisture content of 30\%, 40\%, and 50\%; and rice and wood samples with variations in moisture content of $40 \%$ and $50 \%$. The torefaction was carried out at a temperature of 3000 C for one hour and inert gas N2. Torefaction products have been tested contain of the calorific value, proximate testing, and ultimate testing. The results obtained were the best calorific value in the rice sample, the moisture content of $40 \%$ was $6351.1 \mathrm{cal} / \mathrm{g}$ or equivalent to sub-bituminous coal. The proximate and ultimate results of the best heating value are rice samples with $40 \%$ moisture content, fixed carbon $62.95 \%$, volatile matter $27.85 \%$, moisture $7.06 \%$, ash $2.14 \%$, carbon $71.85 \%$, hydrogen. $2.80 \%$, nitrogen $3.17 \%$, and sulfur $0.05 \%$. The calorific value calculation method that is almost close to the test results is the Dulong method, with an average error percentage of $1.63 \%$.
\end{abstract}

Keywords- Municipal Solid Waste, Water Content, Calorific Value, Proximate, Ultimate

How to cite: Imron Rosyadi 1, Ni Ketut Caturwati2 Ahmad Fauzi 3 (2020) EFFECT OF WATER CONTENT ON CHARACTERISTICS FUEL
FROM THE MUNICIPAL SOLID WASTE THROUGH THE PYROLYSIS PROCESS. R.E.M. (Rekayasa Energi Manufaktur) Jurnal I Vol. 5 no. 2 | doi: $10.21070 /$ rem.v\%vi\%i.974

\section{INTRODUCTION}

\subsection{Background}

Indonesia is one of the countries with the largest population in the world. When viewed from the order in the world, Indonesia is a country with the fourth population in the world. Based on data published by the Central Statistics Agency (BPS) in the year 2018 [1], the total population of Indonesia was 261,890,900 in 2017.

Based on data from the Ministry of Environment and Forestry in 2019 [2], the increase in the population of Indonesia is also proportional to the increase in the amount of waste produced. Indonesia is still facing serious problems in terms of waste management where the national waste generation is 175,000 tonnes per day or the equivalent of 64 million tonnes per year if using the assumption that the waste generated per person per day is $0.7 \mathrm{~kg}$.

Dixon [3] mentioned that, Municipal waste originating from residential and non-residential areas is known as domestic waste, while non-domestic waste is waste or waste other than household waste, for example waste from industrial processes. Municipal solid waste
(MSW) is a mixture of waste mainly from residential and commercial waste consisting of food scraps, garden waste, paper products, plastics, and wood.

I Rosyadi,at all, 2013 [4] Tested MSW samples taken from the TPA in Cilegon City. It showed that the sample waste contains water above $50 \%$, while it is known that to become fuel for power plants the permissible moisture content is below $50 \%$. Based on the Ternar triangle diagram, it is known that the composition of the proximate test content of waste to be able to burn without fuel is waste that has a water content (W) below 50\%, an ash content (A) below $60 \%$ and a burning substance $(\mathrm{C})$ above. $25 \%$ by mass.

We need an appropriate method to manage organic waste that has a high moisture content so that it can become an alternative fuel source that can significantly reduce the amount of waste. One of the technologies that can be used to convert waste into solid fuel which has a high heating value is torefaction.

Torefaction or light pyrolysis is a heat treatment process at temperatures of $200-300 \mathrm{oC}$ at atmospheric pressure in the absence of oxygen. The main products of the torefaction process are solids and gases. Waste

\section{d. http://doi.org/10.21070/rem.v5i2.974}

Copyright $(2) 2020$ Author [s]. This is an open-access article distributed under the terms of the Creative Commons Attribution License (CC BY). The use, distribution or reproduction in other forums is permitted, provided the original author(s) and the copyright owner(s) are credited and that the original publication in this journal is cited, in accordance with accepted academic practice. No use, distribution or reproduction is permitted which does not comply with these terms. 
torefaction can produce fuel equivalent to Subbituminous coal. The emission characteristics of torefaction-generated solid fuel combustion gases from municipal solid waste produce exhaust gases that are more environmentally friendly than direct combustion gases [5].

Based on the background of the above problems, the researcher wanted to know the effect of increasing water content in the torefaction process on the calorific value of rice-based municipal solid waste (MSW) and wood pellets (organic waste). The second researcher wants to know the water content that has the best calorific value in municipal solid waste (MSW) torefaction products in order to obtain the heating value according to SNI and the proximate and ultimate.

\subsection{Scope}

a. Raw materials used municipal solid waste (MSW), namely mixed samples $(30 \%$ rice $+70 \%$ wood pellets), rice samples, and wood pellet samples.

b. The water content of the mixed samples were $30 \%, 40 \%$, and $50 \%$; while the moisture content of the rice and wood pellets samples were $40 \%$ and $50 \%$.

c. The temperature is $300 \mathrm{oC}$ with a time of 1 hour. This torefaction process uses N2 gas (Nitrogen) to minimize oxygen in the reactor.

d. The tests carried out were testing the calorific, proximate, and ultimate values of torefactionbased municipal solid waste (MSW) and wood pellet products.

\subsection{Research Objectives}

a. The objectives to be achieved from this research are:

b. Knowing the effect of increasing water content on the calorific value of torefaction samples using rice-based municipal solid waste (MSW) and wood pellets (organic waste).

c. Looking for water content that has the best calorific value in the product of city solid waste torefaction (MSW) based on rice and wood pellets.

d. Obtained proximate and ultimate test results on torefaction of municipal solid waste (MSW) products based on rice and wood pellets which have the best calorific value.

e. Get a method of calculating the calorific value from researchers that is almost close to the test results.

\subsection{Biomass}

\section{Literature Study}

MSW is a heterogeneous raw material, a combination of organic and inorganic waste containing unsorted materials of various sizes, shapes and different chemical compositions. If MSW is used as raw material for waste-to-energy processing plants, there will be variability and instability in operating conditions, which can cause fluctuations in the quality of the final product [6].

Kadir et al [7] mension that currently, waste processing can be done through thermochemical and biological methods. Thermochemical processes include incineration, pyrolys [8], and gasification by Arena [9]. Meanwhile, a common biological method for organic waste is anaerobic process , Silva and Naik, 2007 [10]. The problem with the biological method is the presence of impurities such as plastic that cannot be recycled so that it affects the product gas produced , Jank et al., 2015 [11]. Incineration technology is the controlled combustion of biomass by utilizing heat to generate power through a steam turbine. Chen P, e.1., 2016 [8] said, however, emissions from incinerators can produce various pollutants such as heavy metals, dioxins and furans which are detrimental to human health. Meanwhile, gasification is a partial combustion or oxidation of biomass to produce synthesis gas (Syngas) and ash at high temperatures $\left(>800^{\circ} \mathrm{C}\right)$.

Utilization of MSW using gasification will significantly reduce the amount of waste, reduce problems in the landfill and be an alternative for advanced thermal treatment applications , Kuo P- C, 2014 [12] . Municipal solid waste contains high moisture content between 40 - 80, low carbon content (high $\mathrm{O} / \mathrm{C}$ ratio) and relatively low heating value. So the consequence is that high energy is needed to remove high water content. In addition, due to the low carbon content (high $\mathrm{O} / \mathrm{C}$ ratio) and low heating value, the amount of synthesis gas production, especially hydrogen gas, is relatively low.

\subsection{Cilegon City Municipal Solid Waste}

In 2018 the amount of waste generation in Cilegon City was $1,345.05 \mathrm{~m} 3 /$ day. It is known that the amount of waste generation is directly proportional to the population. Each sub-district in Cilegon City has a different waste generation. It is predicted that the amount of waste generation will continue to increase every year, in line with the population growth. If it is assumed that the waste generation per person per day is 3.25 liters, then the projection of waste generation in Cilegon City in 20192025 is as follows. 


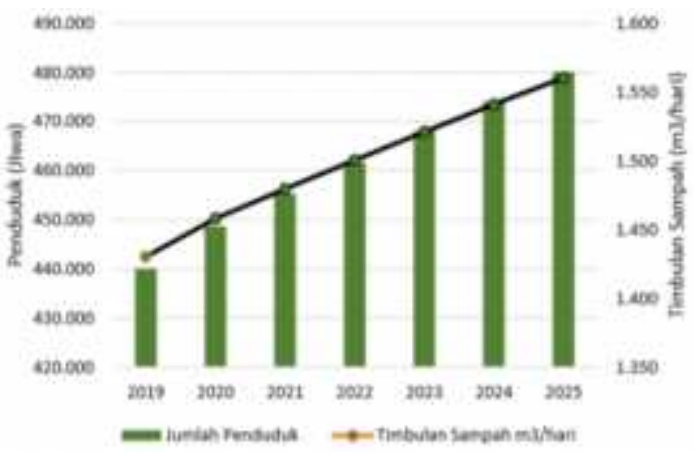

Figure 1. Projection of Cilegon City's Daily Waste Generation 2019-2025

\subsection{Torefaction}

The torefaction process is a relatively mild thermochemical process which involves heating the feedstock to a temperature of 250-350 oC under inert atmospheric conditions. At such temperatures, there is a decrease in water content; The various components of biomass with low calorific value are removed, J. Koppejan, e.1 [13] in years 2012. The heating process of biomass using torefaction can improve the characteristics of biomass as a solid fuel, as evidenced by the increasing calorific value, high energy value, hydrophobia and low water content. The torefaction process produces products in the form of solid, liquid, and a little gas, but what is applied to the torefaction process, the desired product is solid fuel.

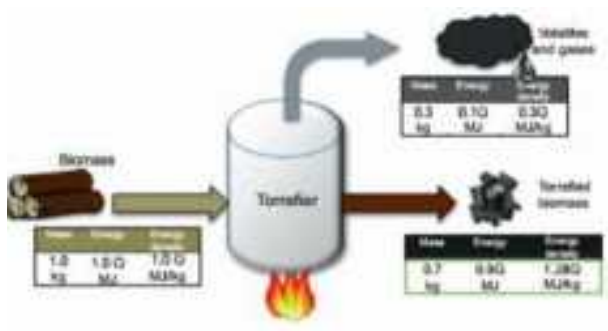

Figure 2. Mechanism of Torefaction

\subsection{Characteristics of Solid Fuels}

The characteristics of the fuel can be determined using two types of analysis, namely proximate analysis and ultimate analysis.

\section{a. Ultimate}

The ultimate analysis is an analysis used to determine the composition of hydrocarbon fuels in the form of basic elements such as carbon $(\mathrm{C})$, hydrogen $(\mathrm{H})$, nitrogen $(\mathrm{N})$, and sulfur $(\mathrm{S})$, and oxygen $(\mathrm{O})$.

$$
\mathrm{C}+\mathrm{N}+\mathrm{H}+\mathrm{S}+\mathrm{O}+\mathrm{ASH}+\mathrm{M}=100 \%
$$

Where $\mathrm{C}, \mathrm{N}, \mathrm{H}, \mathrm{S}$, and $\mathrm{O}$ are the percentage mass fractions of carbon, nitrogen, hydrogen, sulfur and oxygen in solid fuels.

\section{b. Proximate}

Proximate analysis is an analysis used to determine compositions such as fixed carbon (FC), volatile matter (VM), ash content, and moisture content (M) of fuel.

\section{Fixed Carbon (FC)}

Fix carbon is solid carbon in the fuel that is left behind after the devolatization process or after the volatile matter is released. The fixed carbon component provides the highest heating value in a solid fuel.

\section{Volatile Matter (VM)}

Volatile matter is a condensable and noncondensable vapor component that is released when the fuel is heated. The amount of volatile matter depends on the heating level and heating temperature used.

\section{Ash}

Ash is an inorganic solid residue that remains after the fuel burns out. Ash components that contain alkali metals can cause dirt, buildup, and corrosion in the gasifier or boiler.

\section{Moisture Content (MC)}

There are two forms of water content in biomass, namely surface moisture and inherent moisture. Surface moisture is the water content in solid biomass that is outside the cell wall of the biomass. Whereas inherent moisture is the water content that is bound in the cell wall of the biomass.

\subsection{Calorific Value}

The calorific value is a measure of the heat energy in the fuel which is used as an indicator in determining the fuel energy content of each fuel. The heating value of combustion is divided into 2 types, namely:

\section{a. Gross Calorific Value (GCV)}

Gross calorific value is defined as the amount of heat released by the unit mass or volume after the fuel is burned. GCV includes latent heat from evaporation / evaporation of water. GCV is also commonly called Higher Heating Value (HHV). GCV can be obtained using a bomb calorimeter in a laboratory at room temperature.

\section{b. Net Calorific Value (NCV)}

Net calorific value is defined as the amount of heat released from complete combustion minus the heat of water evaporation in the combustion product. NCV is also commonly called Lower Heating Value (LHV). $\mathrm{NCV}$ is produced from the combustion process in water conditions from combustion products in the gas phase.

\section{METODOLOGY}

This research was conducted using literature study methods and experimental methods. Conducting 
literature studies from both text books and journals that have been published and are still relevant in this research. This research was conducted at the Laboratory of Basic Mechanical Phenomena, Department of Mechanical Engineering, Sultan Ageng Tirtayasa University and the Coal Laboratory of PT. Indonesia Power UP Suralaya.

\subsection{Research Flowchart}

\section{Start}

\section{Start Research}

\section{Literature Study}

Collect references related to this research.

\section{Sample Collection}

The sample used was freshly cooked rice with a percentage of bran and water, namely 1: 2, and using wood pellets derived from Dutch teak.

\section{Sample Preparation}

Leftover rice and wood pellets generally contain $64 \%$ and $22 \%$ water content, respectively. To make the standard, the sample is dried at $105 \mathrm{oC}$.
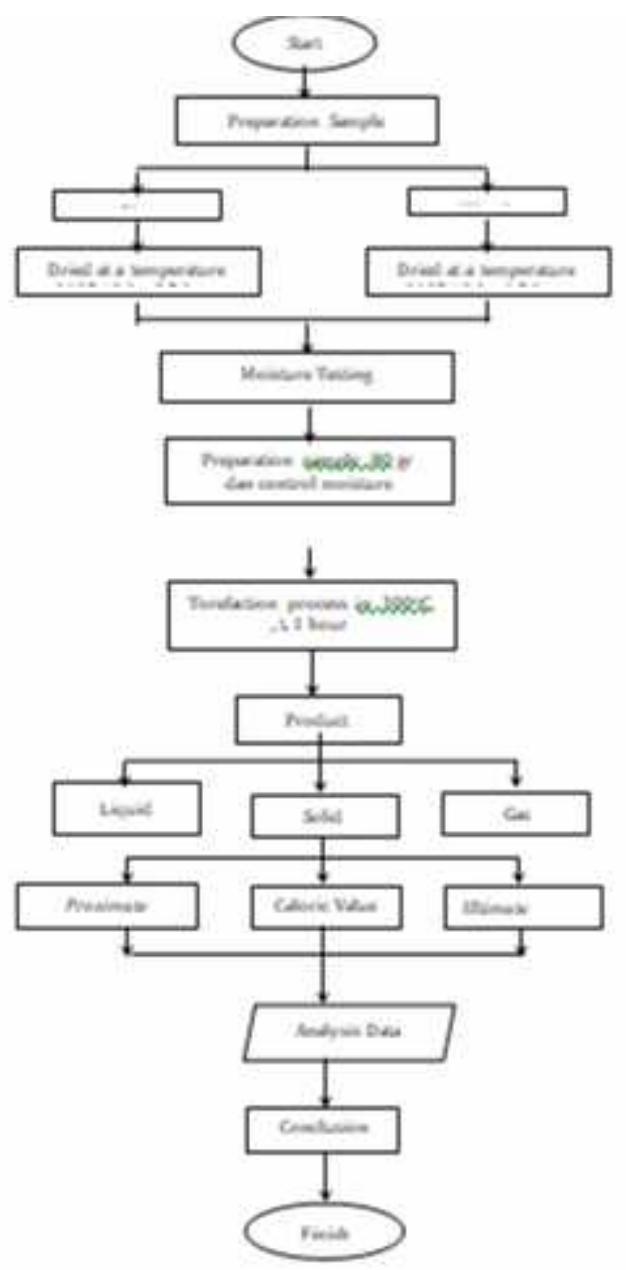

Figure 3. Research Flowchart

5. Testing the Water Content of the Sample
Tests are carried out to get the results of moisture content (moisture). It was found that the water content of the dried rice and wood pellet samples were $17.49 \%$ and $5.72 \%$, respectively.

6. Setting the Water Content in the Sample Adjustment of moisture content in rice and wood pellet samples with variations in water content of $30 \%, 40 \%$, and $50 \%$.

\section{Torefaction Process}

The torefaction carried out in this study used a temperature of $300 \mathrm{oC}$ with N2 (Nitrogen) gas flow and a rate of $1 \mathrm{~L} /$ minute.

\section{Screening of the torefaction results}

The sample was mashed and filtered using a 60 mesh sieve, so that the sample became homogeneous.

9. Calorific Value Testing, Proximate \& Ultimate Tests are carried out to determine the calorific value and characteristics of solid fuel.

10. Result, analysis and Conclusion.

\subsection{Research Variabel}

The fixed (dependent) variables were time, type of biomass, size, and temperature, while the independent variable was moisture content.

The fixed (dependent) variables were the type of biomass used based on rice and wood, the torefaction time was set at 1 hour, and the torefaction temperature was $300 \mathrm{oC}$. While the independent variable, namely the water content of the sample varied $30 \%, 40 \%$, and $50 \%$ for the mixed sample and the water content was $40 \%$, and $50 \%$ for samples of rice and wood pellets.

\subsection{Research Scheme}

The figure 4 is a schematic of the research process carried out. The research started from entering the sample into the torefaction reactor, closing the reactor, adjusting the torefaction temperature to $300 \mathrm{oC}$, adding $11 /$ minute of N2 gas, after 1 hour turning off the heater, opening the reactor lid, and finally taking samples from the reactor..

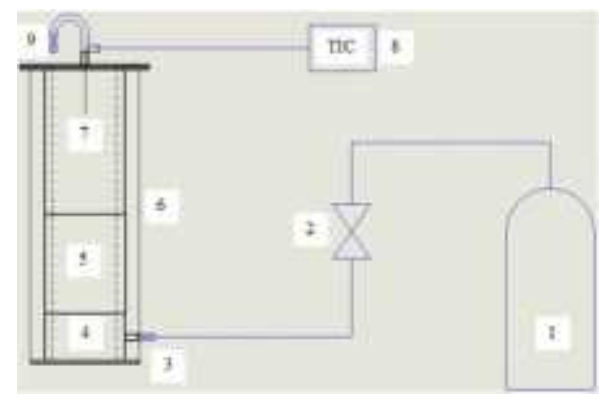

Figure 4. Research Scheme

Information :

\section{d. http://doi.org/10.21070/rem.v5i2.974}



1. Nitrogen Gas (N2)
6. Glass Wool
2. Flow Meter
7. Thermocouple
3. N2 Gas Inlet
8. Thermostat
4. Sample Holder 9. Outlet
5. Heater

\section{RESULT AND DISCUSION}

\subsection{Moisture Content}

Testing of moisture content in samples of leftover rice and wood wood pellets was carried out using the Leco brand TGA-801 at a temperature of $107 \mathrm{oC}$. This water content test used the ASTM D7582 method. Based on the test results, the water content in rice that had been dried for 2.5 hours was $17.49 \%$, while the moisture content in wood pellets that had been dried for 1.5 hours was $5.72 \%$.

Based on the calculation, the mass of water added to achieve the moisture content of $30 \%, 40 \%$, and $50 \%$ in the rice sample were respectively $14.30 \mathrm{gr} ; 30.01 \mathrm{gr}$; and 52.02 gr. While the mass of water added to achieve a moisture content of $30 \%, 40 \%$, and $50 \%$ in the wood pellet samples were 27.75 gr respectively; $45.71 \mathrm{gr}$; and 70.85 gr.

\subsection{Caloric Value}

Table 1.Data of Calorific Value of Torefaction Product

\begin{tabular}{rccc}
\hline Sampel & \multicolumn{3}{c}{ Caloric Value (kal/gr) } \\
& & Moisture \\
& $30 \%$ & $40 \%$ & $50 \%$ \\
\hline $\begin{array}{r}\text { Mixed } \\
\text { Mice }+\end{array}$ & 5457,8 & 5500,1 & 5530,5 \\
$70 \%$ Wood $)$ & & & \\
\hline Nasi & - & 6351,1 & 6186,6 \\
\hline Wood & - & 4655,1 & 5246,2 \\
\hline
\end{tabular}

The best results for the rice sample, the water content was $40 \%$, which was $6351.1 \mathrm{cal} / \mathrm{gr}$ and the lowest was the wood pellet sample with $40 \%$ moisture content, which was $4655.1 \mathrm{cal} /$ gr.

From the calorific value, it can be analyzed the effect of water content in the torefaction process, especially the mixture and wood pellet samples resulting in an increase in heating value, while the rice sample results in a decrease in calorific value. The higher the water content value in the mixture and wood pellet sample, the higher the calorific value of the torefaction results. In contrast to the rice sample, the higher the water content value, the lower the calorific value of the torefaction results.

\subsection{Proximate Analysis}

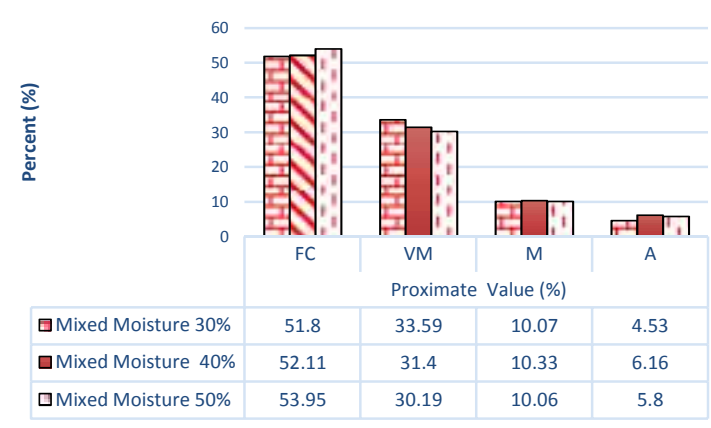

Figure 5. Graph of Mixed Sample Proximate Value on moisture content

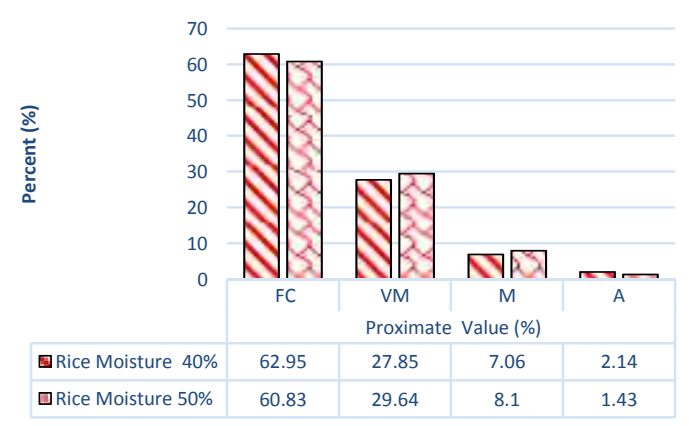

Figure 6. Graph of Proximate Test Results of Rice Samples on moisture content

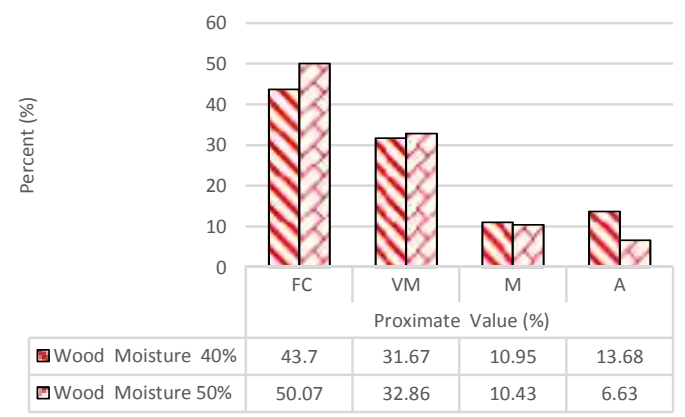

Figure 7. Graph of Proximate Value of Wood Pellet Samples on moisture content

Based on Figure 5, Figure $6 \&$ Figure 7, the shape of the graph of the proximate test results for all samples is almost the same, namely the highest, namely fix carbon, then volatile matter, moisture, and finally ash. However, there is a difference in the graph proximate test results of wood pellet samples with $40 \%$ moisture content, namely the percentage of ash is higher than moisture. Anomaly occurs because the length of time for drying the sample after the torefaction process varies depending on the weather, temperature, and environmental humidity.

\section{d. http://doi.org/10.21070/rem.v5i2.974}


The value of fix carbon in the torefaction sample is directly proportional to the calorific value, the greater the value of the fix carbon, the greater the calorific value of the torefaction sample. Volatile matter affects the value of the fix carbon, the greater the volatile matter value, the smaller the value of the fix carbon and the smaller the calorific value.

\subsection{Ultimate Analysis}

Based on Figure 8, Figure 9, Figure 10, in the graph of the ultimate test results of the three samples, it is found that the carbon element content ranges from 64$71 \%$. The content of the element carbon is much higher than the element hydrogen and nitrogen which is only around 2-3\%. The sulfur content has a very small percentage which only ranges from $0.05-0.15 \%$.

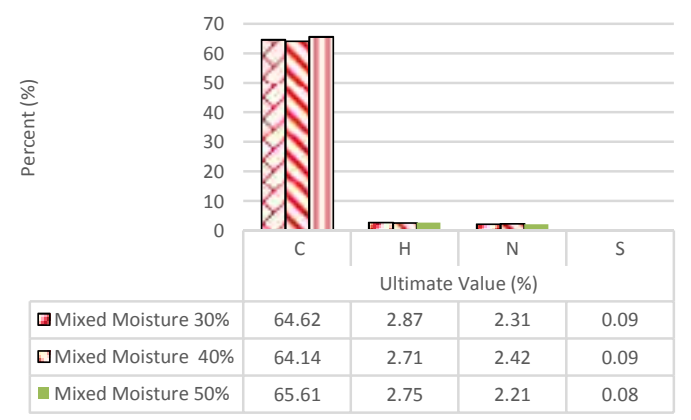

Figure 8. Graph of the Ultimate Value for Mixed Samples on water content

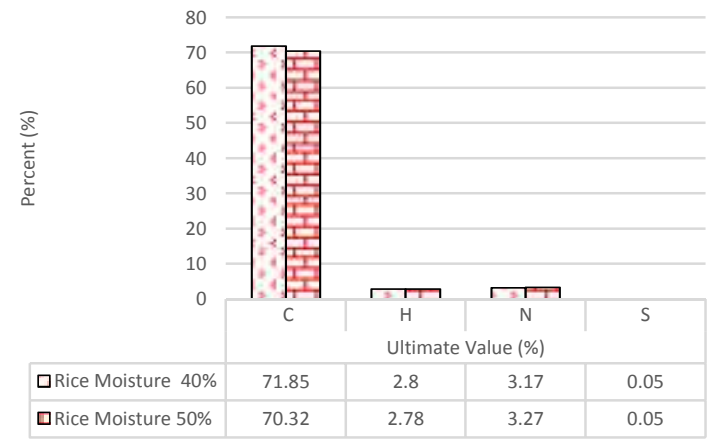

Figure 9. Graph of Ultimate Value of Rice Samples on moisture content.

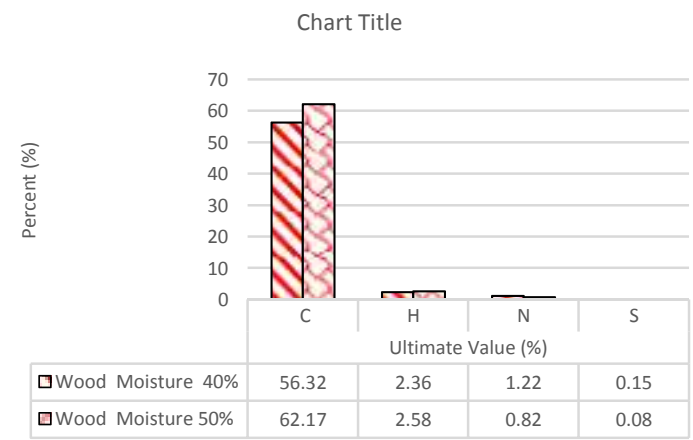

Samples on moisture content

\subsection{Correlation of Calorific Value based on Ultimate Value}

The experimental method using a bomb calorimeter in the laboratory is the most accurate way to determine the calorific value of a solid fuel. However, if the conditions are inadequate, the empirical relationship between ultimate value and heating value (HHV) can be used as another option to find the calorific value of the fuel. In this calculation using the calorific value correlation of Dulong (1880), Vondrecek (1927), and Boie (1953).

Before calculating the heating value in the correlation formula, first look for the percentage of oxygen $(\mathrm{O})$ in the sample, because the ultimate test does not look for the percentage of oxygen.

The formula for the percentage of oxygen in the sample.

$$
\mathrm{O}=100-(\mathrm{M}+\mathrm{A}+\mathrm{S}+\mathrm{C}+\mathrm{H}+\mathrm{N})
$$

\section{a. Correlation of Calorific Value from Dulong}

$$
\mathrm{HHV}=0,3383 \times \mathrm{C}+1,443\left(\mathrm{H}-\left(\frac{\mathrm{O}}{8}\right)\right)+0,0942
$$

Calculation for mixed sample moisture content $30 \%$

$$
\begin{aligned}
& \mathrm{HHV}=0,338 \times 64,62+1,443\left(2,87-\left(\frac{15,51}{8}\right)\right) \\
& +0.0942 \times 0,09
\end{aligned}
$$

\section{b. Correlation of Vondrecek's Calorific Value}

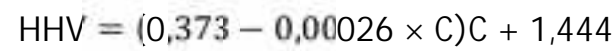

$$
\left(\mathrm{H}-\left(\frac{0}{10}\right)\right)+0,1047 \times \mathrm{S} .
$$

Calculation for mixed sample moisture content $30 \%$

$$
\begin{aligned}
& \mathrm{HHV}=(0,373-0,00026 \times 64,62) 64,14 \\
& +1,444\left(2,78-\left(\frac{14,15}{10}\right)\right)+0,1047 \times 0,09
\end{aligned}
$$$$
\mathrm{HHV}=24,93162546 \approx 24,93 \mathrm{MJ} / \mathrm{kg}
$$

Figure 10. Graph of Ultimate Value of Wood Pellet 


$$
\begin{aligned}
& \mathrm{HHV}=24,93 \frac{\mathrm{MJ}}{\mathrm{kg}} \times \frac{10^{6} \mathrm{~J}}{1 \mathrm{MJ}} \times \frac{1 \mathrm{~kg}}{1000 \mathrm{gr}} \times \frac{0,2389 \mathrm{kal}}{1 \mathrm{~J}} \\
& \mathrm{HHV}=5.955,777 \approx 5.955,8 \mathrm{kal} / \mathrm{gr}
\end{aligned}
$$

\section{c. Correlation of Boie's Calorific Value}

$$
\begin{aligned}
\mathrm{HHV} & =0,3517 \times \mathrm{C}+1,1626 \times \mathrm{H}+0,1047 \times \mathrm{S} \\
& -0,111 \times \mathrm{O} \ldots \ldots \ldots . .(5)
\end{aligned}
$$

Calculation for mixed sample moisture content $30 \%$

$$
\begin{gathered}
\mathrm{HHV}=0,3517 \times 64,62+1,1626 \times 2,87+0,1047 \\
\times 0,09-0,111 \times 15,51
\end{gathered}
$$

\begin{tabular}{|c|c|c|c|c|c|c|c|c|}
\hline \multirow{4}{*}{$\mathrm{No}$. } & \multirow{4}{*}{ Sampel Hasil Torefkssi } & \multirow{3}{*}{$\begin{array}{l}\text { Itimate } \\
\text { Testal }\end{array}$} & \multicolumn{6}{|c|}{ Calarix Valac } \\
\hline & & & \multirow{2}{*}{\multicolumn{2}{|c|}{$\begin{array}{l}\text { Metode } \\
\text { Dubog }\end{array}$}} & \multirow{2}{*}{\multicolumn{2}{|c|}{-Mesde Nentrock }} & \multirow{2}{*}{\multicolumn{2}{|c|}{$\begin{array}{l}\text { Metade } \\
\text { Boxi }\end{array}$}} \\
\hline & & & & & & & & \\
\hline & & kalig & bily & & balig: & & kalige & 10 \\
\hline 1 & Mind Moisture 30\% & 5457,8 & 5544 & 159 & 5955,8 & 9,12 & $\$ 816,2$ & 6,5 \\
\hline 2 & Mined Moisure 40\% & 5900,1 & 5509 & 0,16 & 598,6 & 7,43 & 5767,5 & 48 \\
\hline 3 & Mitod Moisure $50 \%$ & 5530,5 & 56698 & 2,5 & 6063,9 & 9.65 & 9919,4 & 78 \\
\hline 4 & Rowe Mosidure 4he & 6351,1 & 62147 & 2,15 & 660,1 & 3,95 & 6471,5 & 1,: \\
\hline 5 & Roce Mosture SW: & 6186,6 & 60059 & 2,4 & 6433,7 & 399 & 607,7 & 15 \\
\hline 6 & Wood Moisture $4 \pi \%$ & 4655,1 & 47075 & 1,13 & 5111,5 & 9.81 & 89839 & $7 x$ \\
\hline 7 & Wood Moisure 50\% & 5246,2 & 3169,6 & 1,46 & 5995,1 & 6,65 & 5482,4 & \\
\hline
\end{tabular}

$\mathrm{HHV}=24,351329 \approx 24,35 \mathrm{MJ} / \mathrm{kg}$

$$
\begin{aligned}
& \mathrm{HHV}=24,35 \frac{\mathrm{MJ}}{\mathrm{kg}} \times \frac{10^{6} \mathrm{~J}}{1 \mathrm{MJ}} \times \frac{1 \mathrm{~kg}}{1000 \mathrm{gr}} \times \frac{0,2389 \mathrm{kal}}{1 \mathrm{~J}} \\
& \mathrm{HHV}=5.817,215 \approx 5.817,2 \mathrm{kal} / \mathrm{gr}
\end{aligned}
$$

Table 2. Data of Calorific Value from varian methods

From the calculation of the calorific value based on the correlation of the ultimate value, the average percent error in the Dulong Method is $1.63 \%$, the Vondrecek Method is $7.29 \%$, and the Boie Method is $6.84 \%$. From the calculation of the three methods, the average percent error is below $8 \%$. The calorific value calculation method that is almost close to the test results is the Dulong method, with an average error percentage of $1.63 \%$. After being calculated, a comparison graph is made between the calorific value of the test results and the results of the calculation of several methods, the Dulong Method calculation graph is almost the same as the test results.

\subsection{Mass Yield and Energy Yield}

In the torefaction process, the mass yield of biomass in solid form and mass yield occurs from the sample before torefaction. Mass yield is the initial mass fraction of the biomass which will remain in the torefaction product. Energy yield is the fraction of the initial energy of biomass that is retained after torefaction. After torefaction, the energy-rich components will remain in the biomass. This results in a loss of energy (energy yield) of biomass as a whole, even though there is an increase in energy.

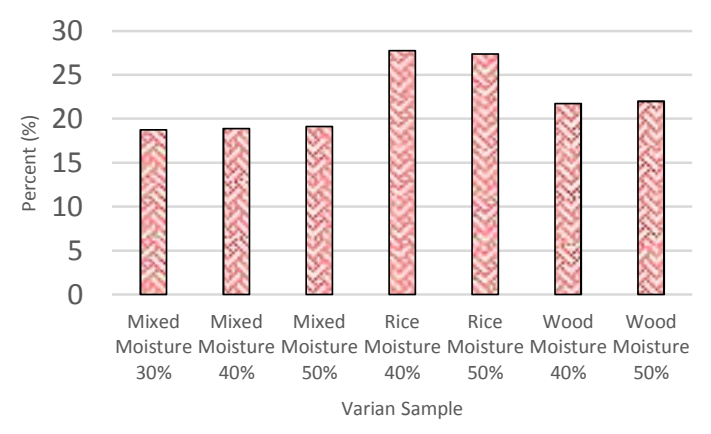

Figure 12. Graph of Mass Yield to moisture content

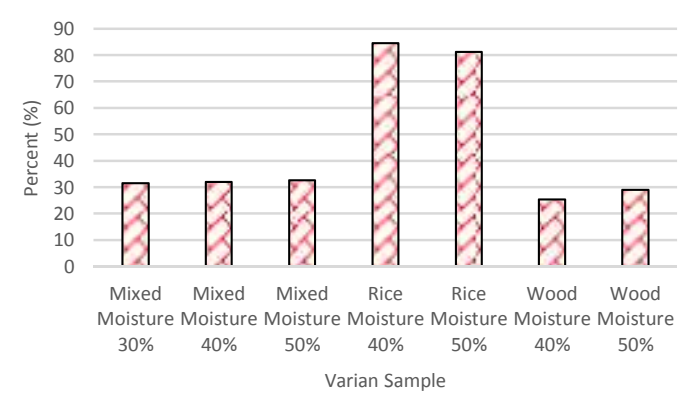

Figure 13. Graph of Energy Yield to moisture content

Based on the percentage loss of mass (mass yield) of the torefaction sample, the percentage of mass yield from the mixture and wood pellet samples was obtained, the higher the moisture content, the higher the mass yield percentage. In the food rice sample, the higher the moisture content, the mass yield percentage decreased.

Based on the percentage of energy loss (energy yield) of the torefaction sample, the percentage of energy yield from the mixed sample and wood pellet sample is obtained, the higher the water content value, the higher the energy yield percentage. In the food rice sample, the higher the water content, the lower the energy yield percentage. The percentage of energy yield is directly proportional to the percentage of mass yield.

From the graph, it was found that the highest mass yield was in the food sample, the moisture content was $40 \%$, which was $27.75 \%$ and the lowest mass yield was found in the mixed sample, the water content was 30\%, which was $18.75 \%$. The highest energy yield was also obtained in the food rice sample, the water content was $40 \%$, which was $84.52 \%$ and the lowest energy yield was found in the wood pellet sample with $40 \%$ moisture content, namely $25 \%$.

\section{d. http://doi.org/10.21070/rem.v5i2.974}




\section{CONCLUSION}

The conclusions obtained from the research that have been done are:

1. The effect of increasing the water content of the sample torefaction results of the mixed sample and wood pellet sample resulted in an increase in calorific value, while the rice sample resulted in a decrease in calorific value.

2. The best calorific value is the rice sample with $40 \%$ moisture content of $6351.1 \mathrm{cal} / \mathrm{g}$ or equivalent to sub-bituminous coal.

3. The proximate and ultimate results of the best heating value are rice samples with $40 \%$ moisture content, fixed carbon $62.95 \%$, volatile matter $27.85 \%$, moisture $7.06 \%$, ash $2.14 \%$, carbon $71.85 \%$, hydrogen $2.80 \%$, nitrogen $3.17 \%$, and sulfur $0.05 \%$.

4. The method of calculating the calorific value that is almost close to the test results is the Dulong method, with an average error percentage of $1.63 \%$.

\section{REFERENCES}

[1] Badan Pusat Statistik. 2018. Statistical Yearbook of Indonesia 2018. Jakarta: Badan Pusat Statistik

[2] Kementerian Lingkungan Hidup dan Kehutanan. 2019. "Gerakan Pilah Sampah Dari Rumah Resmi Diluncurkan" dalam http://pslb3.menlhk.go.id/read/gerakan-pilahsampah-dari-rumah-resmi-diluncurkan. diakses 15 Oktober 2019.

[3] Dixon Neil, D. Russell dan V. Jones. 2004. Engineering Properties of Municipal Solid Waste. Department of Civil and Building Engineering, Loughborough University, Leicestershire, LE11 3TU, UK.

[4] Imron Rosyadi, Agung Sudrajat, Diki M Nurdin , 2013, Uji karakteristik sampah kota cilegon sebagai bahan bakar untuk pembangkit listrik tenaga sampah, Prosiding Seminar Nasional Mesin dan Teknologi Kejuruan.

[5] Hardianto T., Suwono A., Pasek A.D. dan Amrul. 2010. Karakteristik Sifat-Sifat Pembakaran Bahan Bakar Padat Ramah Lingkungan yang Berasal dari Sampah Kota, Digital Proceeding Seminar Nasional Tahunan Teknik Mesin IX, Hotel Arya Duta Palembang, 13-15 Oktober 2010, ISBN: 978- 602-97742-0-7.

[6] L.Helsen, A. Bosmans, Waste-to-Energy through thermochemical processes: matching waste with process, Houthalen-Helchteren, Belgium, in: 1st Int. Symposium on Enhanced Landfill Mining, 2010.

[7] Kadir, S.A.S.A., Yin, C.-Y., Sulaiman, M.R., Che, X., El-Harbawi, M., 2013. Incineration of municipal solid waste in Malaysia: salient issues, policies and waste-to- energy initiatives. Renew. Sustain. Energy Rev. 24,181-186. http://dx.doi.org/10.1016/j.rser.2013.03.041.
[8] Chen P, Xie Q, Addy M, Zhou W, Liu Y, Wang Y, Cheng Y, Li K, Ruan R. Utilization of municipal solid and liquid wastes for bioenergy and bioproducts production. Bioresource Technol 2016; 215:163-172.

[9] Arena, U., 2012. Process and technological aspects of municipal solid waste gasification. A review. Waste Manage. 32, 625-639. http://dx.doi.org/10.1016/ j.wasman.2011.09.025.

[10] Silva.M.R.O, Naik, T.R., 2007. Review of composting and anaerobic digestion Of municipal solid waste and a methodological proposal for a mid-size city. Sustain. Construct. Mater. Technol. - Int. Conf. Sustain. Constr. Mater. Technol.,631-643

[11] Jank, A., Müller, W., Schneider, I., Gerke, F., Bockreis, A., 2015. Waste Separation Press (WSP): a mechanical pretreatment option for organic waste from source separation. Waste Manage. 39, 71-77. http://dx.doi.org/10.1016/j. wasman.2015.02.024.

[12] Kuo P-C, Wu W, Chen W-H. Gasification performances of raw and torrefied biomass in a downdraft fixed bed gasifier using thermodynamic analysis. Fuel 2014; 117:12311241

[13] J. Koppejan, S. Sokhansanj, S. Melin, S. Madrali, Status overview of torrefaction technologies, Int. Energy Agency (IEA) Bioenergy Task 32 Rep. (2012) 1-49.

\section{Conflict of Interest Statement:}

The author declares that the research was conducted in the absence of any commercial or financial relationships that could be construed as a potential conflict of interest.

\section{Article History:}

Received: 20 Oktober 2020| Accepted: 23 November 2020 | Published: 27 Desember 2020 
